\title{
Linkage between community diversity of sulfate-reducing microorganisms and methylmercury concentration in paddy soil
}

\author{
Yu-Rong Liu • Yuan-Ming Zheng • Li-Mei Zhang • \\ Ji-Zheng He
}

Received: 30 March 2013 / Accepted: 1 July 2013 /Published online: 31 July 2013

(C) Springer-Verlag Berlin Heidelberg 2013

\begin{abstract}
Sulfate-reducing microorganisms (SRM) have been thought to play a key role in mercury $(\mathrm{Hg})$ methylation in anoxic environments. The current study examined the linkage between SRM abundance and diversity and contents of methylmercury (MeHg) in paddy soils collected from a historical $\mathrm{Hg}$ mining area in China. Soil profile samples were collected from four sites over a distance gradient downstream the $\mathrm{Hg}$ mining operation. Results showed that $\mathrm{MeHg}$ content in the soil of each site significantly decreased with the extending distance away from $\mathrm{Hg}$ mine. Soil $\mathrm{MeHg}$ content was correlated positively with abundance of SRM and the contents of organic matter (OM), $\mathrm{NH}_{4}{ }^{+}, \mathrm{SO}_{4}{ }^{2-}$, and $\mathrm{Hg}$. The abundances of SRM based on dissimilatory (bi) sulfite reductase $(\operatorname{ds} r A B)$ gene at 0 $40 \mathrm{~cm}$ depths were higher than those at $40-80 \mathrm{~cm}$ depth at all sites. The SRM community composition varied in the soils of different sampling sites following terminal restriction fragment length polymorphism (T-RFLP) and phylogenetic analyses, which appeared to be correlated with contents of $\mathrm{MeHg}, \mathrm{OM}$, $\mathrm{NH}_{4}{ }^{+}$, and $\mathrm{SO}_{4}{ }^{2-}$ through canonical correspondence analysis. The dominant groups of SRM in the soils examined belonged to Deltaproteobacteria and some unknown SRM clusters that could have potential for $\mathrm{Hg}$ methylation. These results advance our understanding of the relationship between SRM and methylmercury concentration in paddy soil.
\end{abstract}

Keywords Rice field · Methylmercury · Sulfate-reducing microorganisms (SRM) · Microbial community . Phylogenetic analysis

Responsible editor: Robert Duran

Y.-R. Liu $\cdot$ Y.-M. Zheng $\cdot$ L.-M. Zhang $\cdot$ J.-Z. He $(\bowtie)$ State Key Laboratory of Urban and Regional Ecology, Research Center for Eco-Environmental Sciences, Chinese Academy of Sciences, Beijing 100085, China

e-mail: jzhe@rcees.ac.cn

\section{Introduction}

Inorganic mercury $\left(\mathrm{Hg}^{2+}\right)$ can be transformed into highly neurotoxic methylmercury $(\mathrm{MeHg})$ via microbial processes that involve sulfate or iron reduction in anaerobic environments (Pak and Bartha 1998; Schaefer et al. 2011; Yu et al. 2012; Hsu-Kim et al. 2013). Most Hg in soil is detected as ionic $\mathrm{Hg}^{2+}$ species and shows relatively low toxicity, however, it still poses some environmental risk due to potential for $\mathrm{Hg}$ methylation followed by bioamplification in soilplant systems (Meng et al. 2010; Liu et al. 2012). Earlier studies have examined microbial methylation of $\mathrm{Hg}$ in estuarine, wetland, and freshwater sediments (Gilmour et al. 1992; Heyes et al. 2006; Duran et al. 2008; Todorova et al. 2009), but little attention to date has been paid to the linkage between specific types of microorganism and $\mathrm{Hg}$ methylation in soil environments. Since some studies reported high $\mathrm{MeHg}$ contents in both of soil and rice in the Wanshan $\mathrm{Hg}$ mine area of Guizhou province in southwest China (Feng et al. 2008; Zhang et al. 2010), concerns have been raised about the fate of $\mathrm{Hg}$ and potential production of $\mathrm{MeHg}$ in the local soil-rice system. However, the mechanism of $\mathrm{Hg}$ methylation by microorganism in environment remains poorly understood (Park et al. 2013).

Sulfate-reducing microorganisms (SRM) is a phylogenetically diverse microbial group that contributes important function in soil including sulfate reduction, terminal oxidation of organic carbon, $\mathrm{Hg}$ methylation, and biodegradation of organic pollutants in anaerobic environments (Coates et al. 1996; Dhillon et al. 2003; Fitzgerald et al. 2007; He et al. 2010). Since the study on SRM pure-culture strains Desulfovibrio deseulfuricans first demonstrating its capacity for $\mathrm{Hg}$ methylation (Choi et al. 1994), many studies linking $\mathrm{Hg}$ methylation to SRM species were conducted in natural habitats (Compeau and Bartha 1985; King et al. 2000; Benoit 
et at. 2001; Ekstrom et al. 2003). Recently, it was suggested that only SRM belonging to the Deltaproteobacteria group can methylate Hg (Ranchou-Peyruse et al. 2009). Therefore, it was very essential to link the diversity of SRM to $\mathrm{Hg}$ methylation in environments because long-term historical evolution or related functional gene transfer may result in different potential for $\mathrm{Hg}$ methylation among various SRM. As a consequence, taxonomic diversity of SRM associating to $\mathrm{Hg}$ methylation in environment has been characterized by recent studies (Yu et al. 2010, 2012), which has enhanced our understanding on the contribution of SRM to $\mathrm{MeHg}$ production. Recently, activity and diversity of SRM in rice field have been widely reported (Scheid and Stubner 2001; Liu et al. 2009; Lin et al. 2010). However, no study is available regarding on the relationship of SRM community diversity with $\mathrm{MeHg}$ concentration in paddy soil.

Paddy soil usually produces an anaerobic environment attributing to the depletion of oxygen in the rice bulk after flooding, which can result in prevalence of anaerobic functional microbes (Liu et al. 2009). Wanshan area is one of important rice producing regions in southwest China, where mean (and range) of $\mathrm{MeHg}$ content in paddy soil was 2.7 (0.27-12) $\mathrm{ng} \mathrm{g}^{-1}$ according to previous reports (Feng et al. 2008; Zhang et al. 2010), a level that poses a serious threat to soil ecosystems and safety for human consumption of rice from this area. Therefore, it is essential to understand the methylation of $\mathrm{Hg}$ by the microorganisms in the paddy soil. The objective of this study was to link ecological characteristics of SRM to the MeHg concentration in the paddy soil, and the obtained results might be helpful to understand microbial methylation of $\mathrm{Hg}$ in rice field. The abundance and diversity of SRM were characterized based on the dissimilatory (bi) sulfite reducase ( $d s r A B$ ) gene, which has been widely used as a biomarker for determining the SRM abundance and diversity in various environments (Geets et al. 2006; Liu et al. 2009; Lin et al. 2010).

\section{Materials and methods}

Study area and sampling

All soil samples examined here were collected from rice fields in the Wanshan $\mathrm{Hg}$ mining area, which is located in the eastern part of Guizhou province, southwest China (Fig. 1). The Wanshan area is a typical hilly and karstic terrain that has a subtropical humid climate. The $\mathrm{Hg}$ mining site is rated the largest $\mathrm{Hg}$ deposit in China, with mining activities first initiated in the Qin Dynasty (circa 221 B.C.). Large-scale production, however, ceased officially in 2001. A long-term history of $\mathrm{Hg}$ mining in the area has led to serious soil $\mathrm{Hg}$ contamination attributing to discharge of waste from the $\mathrm{Hg}$ mine. Four sites (referred to as S1, S2, S3, and S4, respectively) were selected according to their distance away from the $\mathrm{Hg}$ mining site. S1, S2, and S3 are located in Wanshan district while S4 is located in Tongren district, in close proximity to Wanshan district. S4 was used as the control site in the current study, as it was at the greatest distance from the mine site and is considered to have little $\mathrm{Hg}$ contamination. Totally 48 soil samples (three replicates for each one) were taken at different depths $(0-20,20-40,40-60$, and $60-80 \mathrm{~cm})$ at the 4 sites. Soil samples were passed through a $2.0-\mathrm{mm}$ sieve and air-dried for general chemical analyses. For $\mathrm{Hg}, \mathrm{MeHg}$ and molecular analyses, some of sieved soils were stored at $-20{ }^{\circ} \mathrm{C}$. Some basic soil chemical characteristics from the four sites are listed in Table 1.

\section{Chemical analysis}

Soil $\mathrm{pH}$ was determined using a soil to distilled water ratio of $1: 2.5$, and soil organic matter $(\mathrm{OM})$ was determined using the $\mathrm{K}_{2} \mathrm{CrO}_{7}$ oxidation titration method (Walkley and Black 1934). Soil sulfate was extracted with deionized water in a ratio 1:5 and measured via ion chromatography using an AS14 column and an ECD50 conductivity detector (Dionex, USA). Ammonium in soil samples was extracted with $2 \mathrm{M} \mathrm{KCl}$ and determined using a Continuous Flow Analyser (SAN++, Skalar, Holand). For $\mathrm{Hg}$ analysis, soil samples were first digested with $\mathrm{HNO}_{3}+\mathrm{HCl}(10 \mathrm{ml}, 1: 1 \mathrm{v} / \mathrm{v})$ in a teflon tube at $100{ }^{\circ} \mathrm{C}$ for $2 \mathrm{~h}$. Total $\mathrm{Hg}$ concentration was then determined using Inductively Coupled Plasma Mass Spectrometry (ICP-MS). Soil samples were prepared for $\mathrm{MeHg}$ analysis using $\mathrm{CuSO}_{4}$ methanol/solvent extraction according to the method outlined by (Liang et al. 2004), following which MeHg contents were determined using HPLC-ICP-MS.

\section{Soil DNA Extraction and Quantification of $d s r A B$ gene}

DNA was extracted from $0.5 \mathrm{~g}$ of soil samples using UltracleanTM soil DNA Isolation Kits (MoBio Laboratory, USA) according to the manufacturer's protocol. Real-time PCR assay is considered a highly sensitive method to quantify microbial abundance in environmental samples (Smith et al. 2006; Cao et al. 2012). Abundance of SRM was determined here using a quantitative real-time PCR method using an iCycler iQ5 thermocycler (Bio-Rad, USA), based on $d s r A B$ gene sequences. $D s r A B$ gene abundance was quantified in a $25-\mu 1$ reaction mixture containing SYBR ${ }^{\circledR}$ Premix Ex Taq ${ }^{\mathrm{TM}}$ (Takara Biotechnology), using the primer set as described by previous study (Liu et al. 2009).

To prepare standard curves, $d s r A B$ gene sequences were amplified from extracted DNA using the primers DSRM2060F/DSR4R primers (Geets et al. 2006). PCR products were cloned into the pGEM-T Easy Vector (Promega). Plasmids used as standards for quantitative analyses were extracted from the corrected clones of 


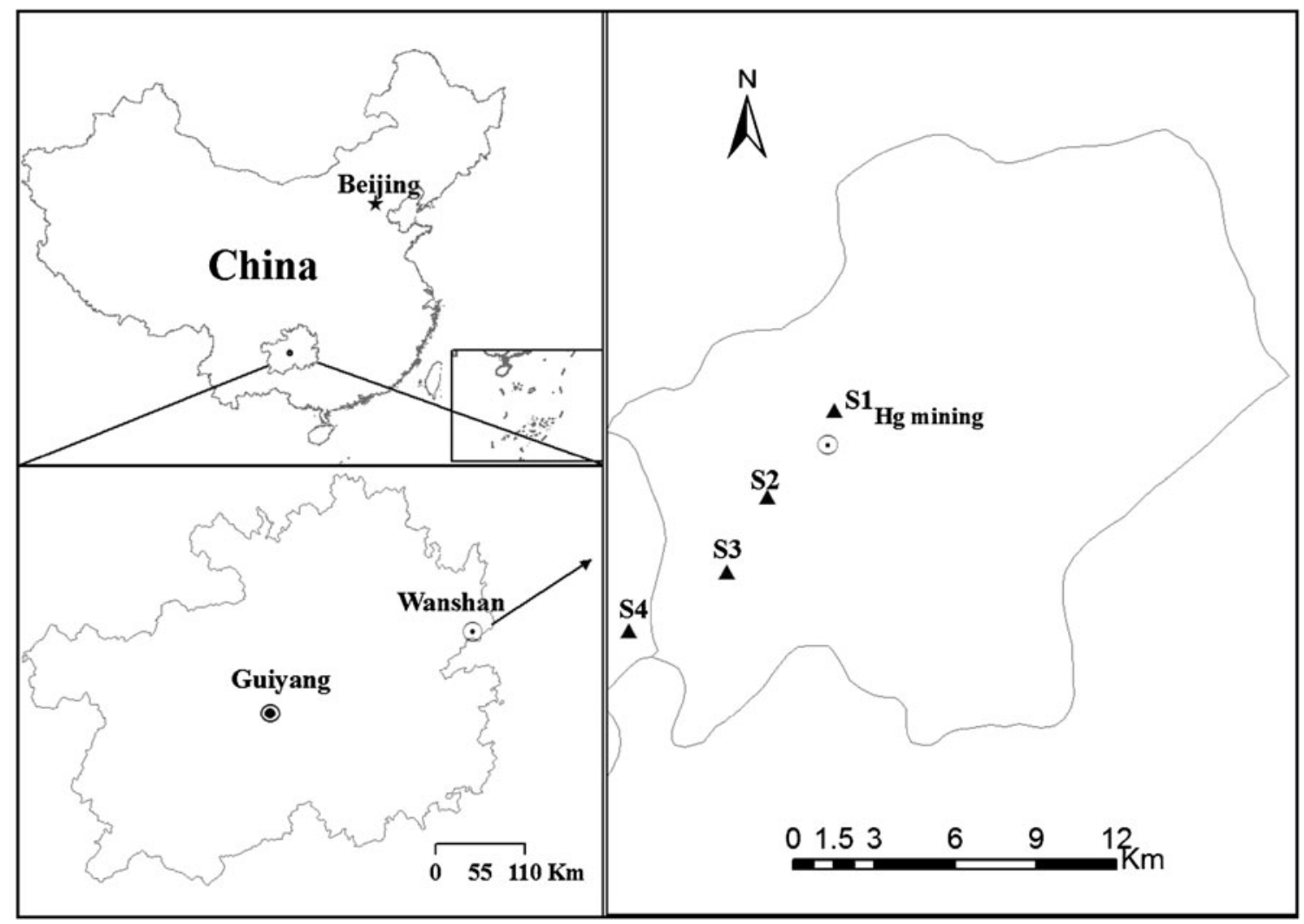

Fig. 1 Map of the study area and sampling locations in Wanshan $\mathrm{Hg}$ mining area (S1, S2, S3, and $S 4$ represent site 1, site 2, site 3, and site 4, respectively)

target gene. Copy numbers of target gene was calculated directly from the concentrations of extracted plasmid DNA. Tenfold serial dilutions of a known copy number of the plasmid DNA were run in real-time PCR assays in triplicate to generate an external standard curve.
Terminal restriction fragment length polymorphism (T-RFLP) analysis

The method of T-RFLP analysis is one of most common molecular techniques for profiling microbial community
Table 1 Chemical properties of the paddy soil samples in the Wanshan $\mathrm{Hg}$ mining area ${ }^{\mathrm{a}}$

\section{$O M$ means organic matter}

${ }^{a} \mathrm{~S} 1, \mathrm{~S} 2, \mathrm{~S} 3$, and S4 represent site 1 , site 2 , site 3 , and site 4 , respectively

${ }^{\mathrm{b}}$ Concentrations do not share the same letter are significantly different $(P<0.05)$

\begin{tabular}{lllll}
\hline Sample (cm) & $\mathrm{pH}\left(\mathrm{H}_{2} \mathrm{O}\right)$ & $\mathrm{OM}(\%)$ & $\mathrm{SO}_{4}^{2-}\left(\mathrm{mg} \mathrm{kg}^{-1}\right)$ & $\mathrm{NH}_{4}^{+}\left(\mathrm{mg} \mathrm{kg}^{-1}\right)$ \\
\hline $\mathrm{S} 1(0-20)$ & $7.43 \pm 0.04 \mathrm{Ab}^{\mathrm{b}}$ & $4.13 \pm 0.70 \mathrm{Aa}$ & $179.48 \pm 7.04 \mathrm{Ab}$ & $11.35 \pm 0.70 \mathrm{Aa}$ \\
$\mathrm{S} 1(20-40)$ & $7.59 \pm 0.03 \mathrm{Aa}$ & $3.41 \pm 0.40 \mathrm{Aab}$ & $209.75 \pm 7.34 \mathrm{Aa}$ & $4.69 \pm 0.42 \mathrm{Ab}$ \\
$\mathrm{S} 1(40-60)$ & $7.45 \pm 0.05 \mathrm{ABb}$ & $2.37 \pm 0.14 \mathrm{Ac}$ & $170.73 \pm 12.2 \mathrm{Ab}$ & $5.32 \pm 1.80 \mathrm{Ab}$ \\
$\mathrm{S} 1(60-80)$ & $7.46 \pm 0.05 \mathrm{Ab}$ & $2.64 \pm 0.22 \mathrm{Abc}$ & $171.08 \pm 18.48 \mathrm{Ab}$ & $4.22 \pm 0.32 \mathrm{Ab}$ \\
$\mathrm{S} 2(0-20)$ & $7.52 \pm 0.03 \mathrm{Ba}$ & $4.87 \pm 0.06 \mathrm{ABa}$ & $361.28 \pm 29.24 \mathrm{Bb}$ & $14.61 \pm 1.33 \mathrm{Ba}$ \\
$\mathrm{S} 2(20-40)$ & $7.43 \pm 0.03 \mathrm{Bb}$ & $4.12 \pm 0.55 \mathrm{Ab}$ & $293.78 \pm 24.32 \mathrm{Bc}$ & $5.75 \pm 0.53 \mathrm{Ab}$ \\
$\mathrm{S} 2(40-60)$ & $7.36 \pm 0.05 \mathrm{Ac}$ & $3.94 \pm 0.40 \mathrm{Bb}$ & $385.45 \pm 12.23 \mathrm{Bb}$ & $5.65 \pm 0.66 \mathrm{Ab}$ \\
$\mathrm{S} 2(60-80)$ & $7.16 \pm 0.04 \mathrm{Bd}$ & $4.08 \pm 0.24 \mathrm{Bb}$ & $436.13 \pm 25.14 \mathrm{Ba}$ & $5.09 \pm 0.68 \mathrm{Ab}$ \\
$\mathrm{S} 3(0-20)$ & $7.40 \pm 0.04 \mathrm{Ab}$ & $6.66 \pm 0.24 \mathrm{Ba}$ & $324.18 \pm 1.31 \mathrm{Ca}$ & $23.29 \pm 1.40 \mathrm{Ca}$ \\
$\mathrm{S} 3(20-40)$ & $7.47 \pm 0.02 \mathrm{Bb}$ & $6.39 \pm 0.09 \mathrm{Bab}$ & $247.95 \pm 3.40 \mathrm{Cb}$ & $8.08 \pm 1.37 \mathrm{Bb}$ \\
$\mathrm{S} 3(40-60)$ & $7.52 \pm 0.09 \mathrm{Ba}$ & $5.57 \pm 1.08 \mathrm{Cb}$ & $160.00 \pm 18.65 \mathrm{Ac}$ & $6.94 \pm 0.50 \mathrm{Bb}$ \\
$\mathrm{S} 3(60-80)$ & $7.50 \pm 0.04 \mathrm{Ab}$ & $5.14 \pm 0.17 \mathrm{Cb}$ & $158.03 \pm 16.01 \mathrm{Ac}$ & $8.18 \pm 1.53 \mathrm{Bb}$ \\
$\mathrm{S} 4(0-20)$ & $7.01 \pm 0.08 \mathrm{Cc}$ & $5.22 \pm 0.60 \mathrm{Aa}$ & $168.83 \pm 19 \mathrm{Aa}$ & $8.97 \pm 0.59 \mathrm{Da}$ \\
$\mathrm{S} 4(20-40)$ & $7.46 \pm 0.05 \mathrm{Bb}$ & $3.62 \pm 0.35 \mathrm{Ab}$ & $62.87 \pm 14.73 \mathrm{Db}$ & $3.48 \pm 3.32 \mathrm{Cb}$ \\
$\mathrm{S} 4(40-60)$ & $7.77 \pm 0.06 \mathrm{Ba}$ & $2.44 \pm 0.15 \mathrm{Ac}$ & $40.17 \pm 6.57 \mathrm{Cb}$ & $3.58 \pm 0.46 \mathrm{Cb}$ \\
$\mathrm{S} 4(60-80)$ & $7.64 \pm 0.16 \mathrm{Cb}$ & $1.57 \pm 0.19 \mathrm{Dd}$ & $52.75 \pm 4.95 \mathrm{Cb}$ & $3.03 \pm 0.78 \mathrm{Cb}$ \\
\hline
\end{tabular}



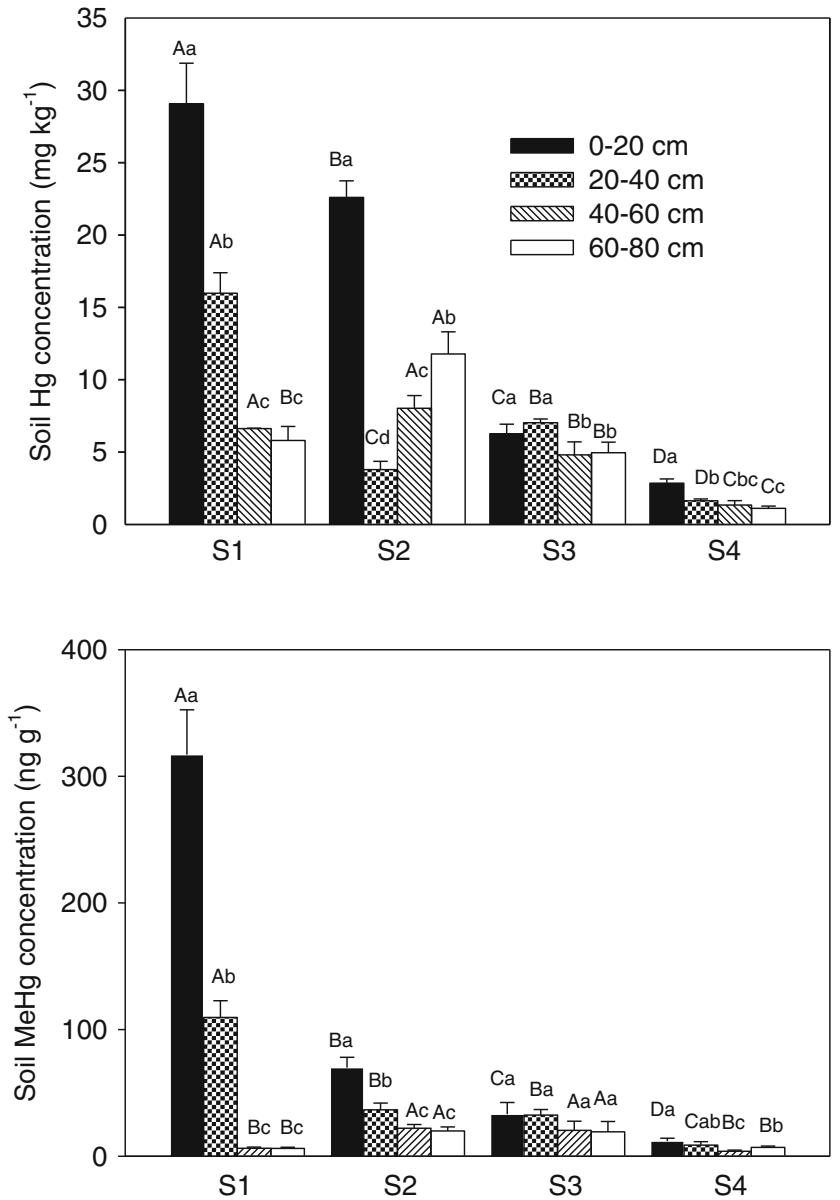

Fig. $2 \mathrm{Hg}$ and methylmercury $(\mathrm{MeHg})$ concentrations in the different depth soil from the four sites. Capital letters indicate the significant differences among sites at the same soil depth $(P<0.05)$. Lowercase letters indicate the significant differences among soil depths at the same site $(P<0.05)$. Small bars show standard errors

(Li et al. 2013). For the T-RFLP analysis of $d s r A B$ gene, the 5 ' end of DSRAB_F forward primer was labeled with 5carboxyfluorescein (FAM) for PCR amplification (Schmalenberger et al. 2007). A 50- $\mu$ l reaction mixture contained $4 \mu \mathrm{l}$ of template DNA, $5 \mu \mathrm{l} 10 \times E x$ Taq buffer $\left(\mathrm{Mg}^{2+}\right.$ plus), $1 \mu \mathrm{l}$ bovine serum albumin (BSA, $25 \mathrm{mM}$ ), $4 \mu \mathrm{l}$ dNTPs $(2.5 \mathrm{mM})$ and $1 \mu \mathrm{l}$ of each primer of $d s r A B$ gene
$(10 \mu \mathrm{M})$, and $0.5 \mu \mathrm{l} \operatorname{Ex} \operatorname{Taq} H S\left(5 \mathrm{U} \mu \mathrm{l}^{-1}\right.$; Takara, Japan). The thermal profile for amplification was as follows: $3 \mathrm{~min}$ at $94{ }^{\circ} \mathrm{C} ; 35$ cycles of $1 \mathrm{~min}$ at $94^{\circ} \mathrm{C}, 1 \mathrm{~min}$ at $60^{\circ} \mathrm{C}$, and $3 \mathrm{~min}$ at $72{ }^{\circ} \mathrm{C}$; and a final extension at $72{ }^{\circ} \mathrm{C}$ for $10 \mathrm{~min}$. FAMlabeled PCR products were purified using the Wizard ${ }^{\circledR} \mathrm{SV}$ Gel and PCR Clean-Up System (Promega, USA). Aliquots $(5 \mu \mathrm{l})$ were digested with $5 \mathrm{U}$ Hha I (Takara, Japan) in a final volume of $20 \mu \mathrm{l}$ at $37^{\circ} \mathrm{C}$ for $1.5 \mathrm{~h}$. Digested amplicons were precipitated with $2 \mu \mathrm{l}$ of $3 \mathrm{M} \mathrm{NaOAc}$ and $40 \mu \mathrm{l}$ of absolute alcohol at $-20{ }^{\circ} \mathrm{C}$ for $30 \mathrm{~min}$. DNA pellets were washed in $70 \%$ ethanol and then dissolved in distilled water. Fluorescently labeled fragments were separated and detected by capillary electrophoresis in an ABI PRISM 3700 DNA Analyzer (Applied Biosystems, USA) under GeneScan mode. T-RFLP profiles were analyzed with GeneMapper software (Applied Biosystems, USA). The relative abundance of the individual terminal restriction fragment (T-RF) was estimated by reference to the internal size standard GeneScan-1000 LIZ (Applied Biosystems, USA). Proportional abundances of individual T-RFs were determined as the peak area of the respective T-RF divided by the total peak area of all T-RFs detected within a fragment size that ranged between 50 and $1,000 \mathrm{bp}$. The relative abundance of a T-RF was calculated by dividing the peak height of the T-RF by the total peak height of all T-RFs in the profile. Peaks with heights $\leq 1 \%$ of the total peak height were not included in further analyses.

\section{Cloning, sequencing and phylogenetic analysis}

In order to characterize $d s r A B$ gene diversity based on the TRFLP analysis, two clone libraries were constructed from top soil (0-20 cm depth) samples at $\mathrm{S} 1$ and $\mathrm{S} 2$, the sites that possessed the most diverse SRM communities. The $d s r A B$ gene was amplified using the same primers as described above without FAM labeling. Purified PCR products ( $800 \mathrm{bp}$ ) were ligated into the pGEM-T Easy Vector (Promega, USA) and then transformed into Escherichia coli JM109 competent cells (Takara, Japan) following the manufacturer's instructions. In total, $200 d s r A B$ gene clones were sequenced. Sequences sharing $>97 \% d s r A B$ gene nucleotide homology were grouped into the same
Table 2 Correlations between abundance of sulfate-reducing microorganisms (SRM), $\mathrm{pH}$, and concentrations of $\mathrm{SO}_{4}{ }^{2-}, \mathrm{OM}$, $\mathrm{NH}_{4}{ }^{+}, \mathrm{Hg}$, and $\mathrm{MeHg}$ in the soil samples

${ }^{*} P<0.05$; ** $P<0.01$, values in bold are statistically significant

\begin{tabular}{|c|c|c|c|c|c|c|}
\hline & \multicolumn{6}{|c|}{ Kendall's correlation coefficient } \\
\hline & Abundance of SRM & $\mathrm{SO}_{4}{ }^{2-}$ & $\mathrm{OM}$ & $\mathrm{pH}$ & $\mathrm{NH}_{4}^{+}$ & $\mathrm{Hg}$ \\
\hline $\mathrm{SO}_{4}{ }^{2-}$ & 0.182 & & & & & \\
\hline $\mathrm{OM}$ & $0.606 * *$ & $0.344 * *$ & & & & \\
\hline $\mathrm{pH}$ & -0.145 & $0.335^{* *}$ & $0.210 *$ & & & \\
\hline $\mathrm{NH}_{4}^{+}$ & $0.413 * *$ & $0.333 * *$ & $0.566 * *$ & $0.210 *$ & & \\
\hline $\mathrm{Hg}$ & 0.11 & $0.559 * *$ & 0.196 & -0.134 & $0.304 * *$ & \\
\hline $\mathrm{MeHg}$ & $0.374 *$ & $0.320 *$ & $0.306^{*}$ & -0.02 & $0.335 * *$ & $0.480 * *$ \\
\hline
\end{tabular}




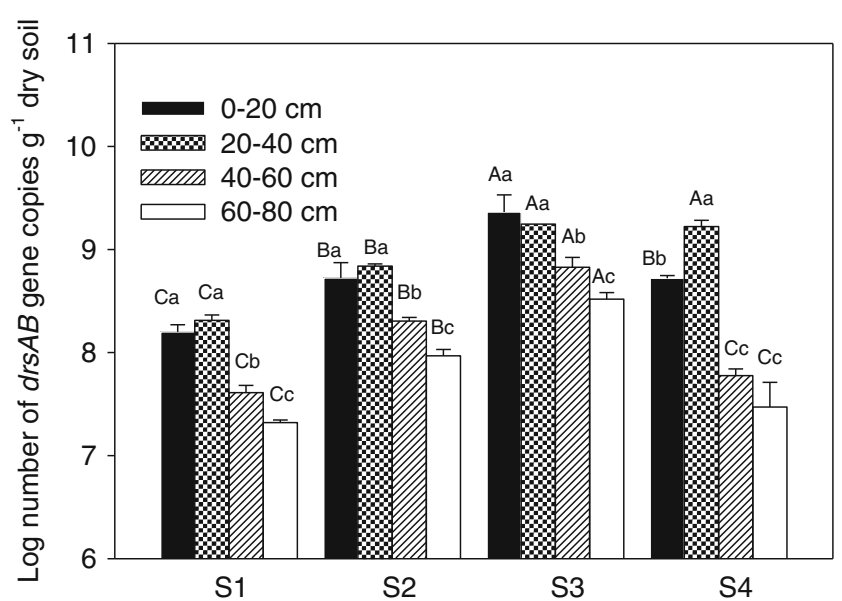

Fig. 3 Sulfate-reducing microorganisms (SRM) abundance based on dissimilatory (bi) sulfite reductase $(\operatorname{ds} A B)$ gene sequences. Capital letters indicate the significant differences among sites at the same soil depth $(P<0.05)$. Lowercase letters indicate the significant differences among soil depths at the same site $(P<0.05)$. Small bars show standard errors

Operational Taxonomy Units (OTUs). Representative sequences of each OTU were aligned and analyzed with Clustal X 1.81 (Thompson et al. 1994). A phylogenetic tree was constructed using MEGA version 5.0 employing a neighbor-joining method applying a Bootstrap value of 1,000 . Sequences from different OTUs were deposited in GenBank nucleotide sequence database under the following accession numbers: JX976939-JX976996.

\section{Statistical analysis}

Copy numbers of $d s r A B$ gene sequences were log-transformed to normalize their distributions for analysis and then subjected to Canonical Correspondence Analysis (CCA; Canoco 4.5 for
Windows) to explore the relationship between the various species detected (characterized by T-RFs with interspecies distances) and environmental factors (soil $\mathrm{pH}$ and the contents of $\mathrm{OM}, \mathrm{NH}_{4}{ }^{+}, \mathrm{SO}_{4}{ }^{2-}, \mathrm{Hg}$, and $\mathrm{MeHg}$, respectively). Variables to be included in the model were chosen by forward selection at the 0.05 baseline. Significance of the constrained ordination process was tested using a Monte Carlo permutation test. Twoway analysis of variance (ANOVA) was used to assess differences of all the obtained variables of soils among the depths and sites, and all the results were represented as means with associated standard errors. Statistical significance was assessed using SPSS 13.0 software. Bivariate correlations were conducted to link different parameters. $P<0.05$ was considered to be significant.

\section{Results and discussion}

$\mathrm{Hg}$ and $\mathrm{MeHg}$ contents in the experimental soils

There was significant difference $(P<0.05)$ of $\mathrm{Hg}$ content among the top soils from the four sites (Fig. 2). Average $\mathrm{Hg}$ contents in the soils declined with geographical distance away from the historic $\mathrm{Hg}$ mine site, which could be attributed to the different levels input of $\mathrm{Hg}$ by atmospheric dispersing or surface water runoff. For example, the S1 is closest to $\mathrm{Hg}$ mine site, where the $\mathrm{Hg}$ contents were both highest in the top soil of S1 compared to the other sites. Furthermore, the lowest Hg contents in the top soil of S4 was comparable to background levels reported elsewhere across China (CNEMS 1990), suggesting that Hg contamination from mining had not reached S4 and also could be used as

$\begin{array}{ll}\square 59 \mathrm{bp} & \square 96 \mathrm{bp} \\ \square 113 \mathrm{bp} & \square 129 \mathrm{bp} \\ \square 147 \mathrm{bp} & \square 153 \mathrm{bp} \\ \square 158 \mathrm{bp} & \square 168 \mathrm{bp} \\ \square 185 \mathrm{bp} & \square 214 \mathrm{bp} \\ \square 241 \mathrm{bp} & \square 274 \mathrm{bp} \\ \square 276 \mathrm{bp} & \square 286 \mathrm{bp} \\ \square 296 \mathrm{bp} & \square 318 \mathrm{bp} \\ \square 322 \mathrm{bp} & \square 334 \mathrm{bp} \\ \square 338 \mathrm{bp} & \square 345 \mathrm{bp} \\ \square 354 \mathrm{bp} & \square 472 \mathrm{bp} \\ \square 500 \mathrm{bp} & \square 505 \mathrm{bp} \\ \square 528 \mathrm{bp} & \square 590 \mathrm{bp} \\ \square 604 \mathrm{bp} & \square 648 \mathrm{bp} \\ \square 680 \mathrm{bp} & \end{array}$

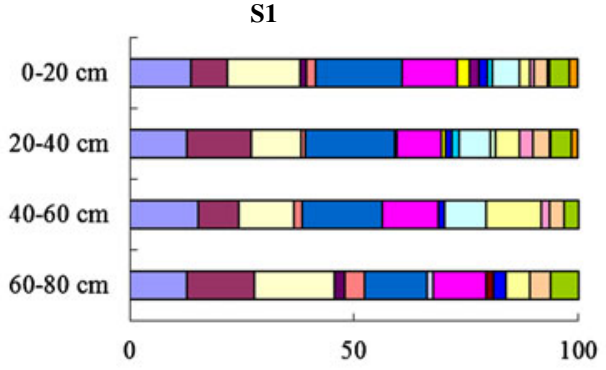

S3

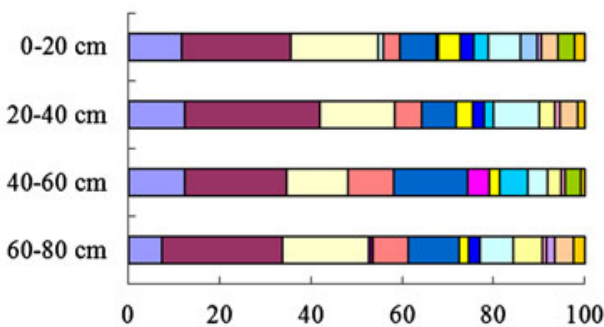

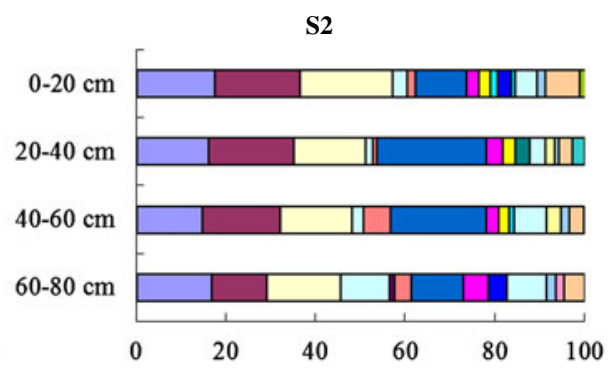

S4

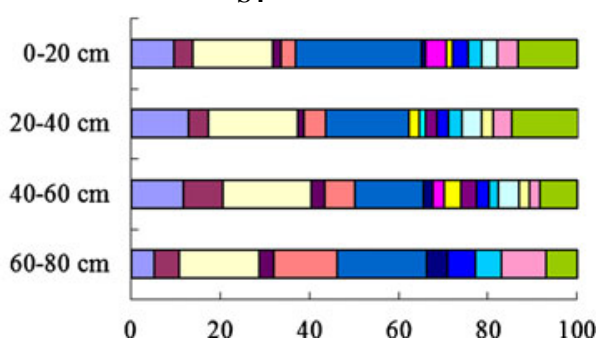

Fig. 4 Terminal restriction fragment length polymorphism (T-RFLP) patterns for the $d s r A B$ gene in different soil profiles 


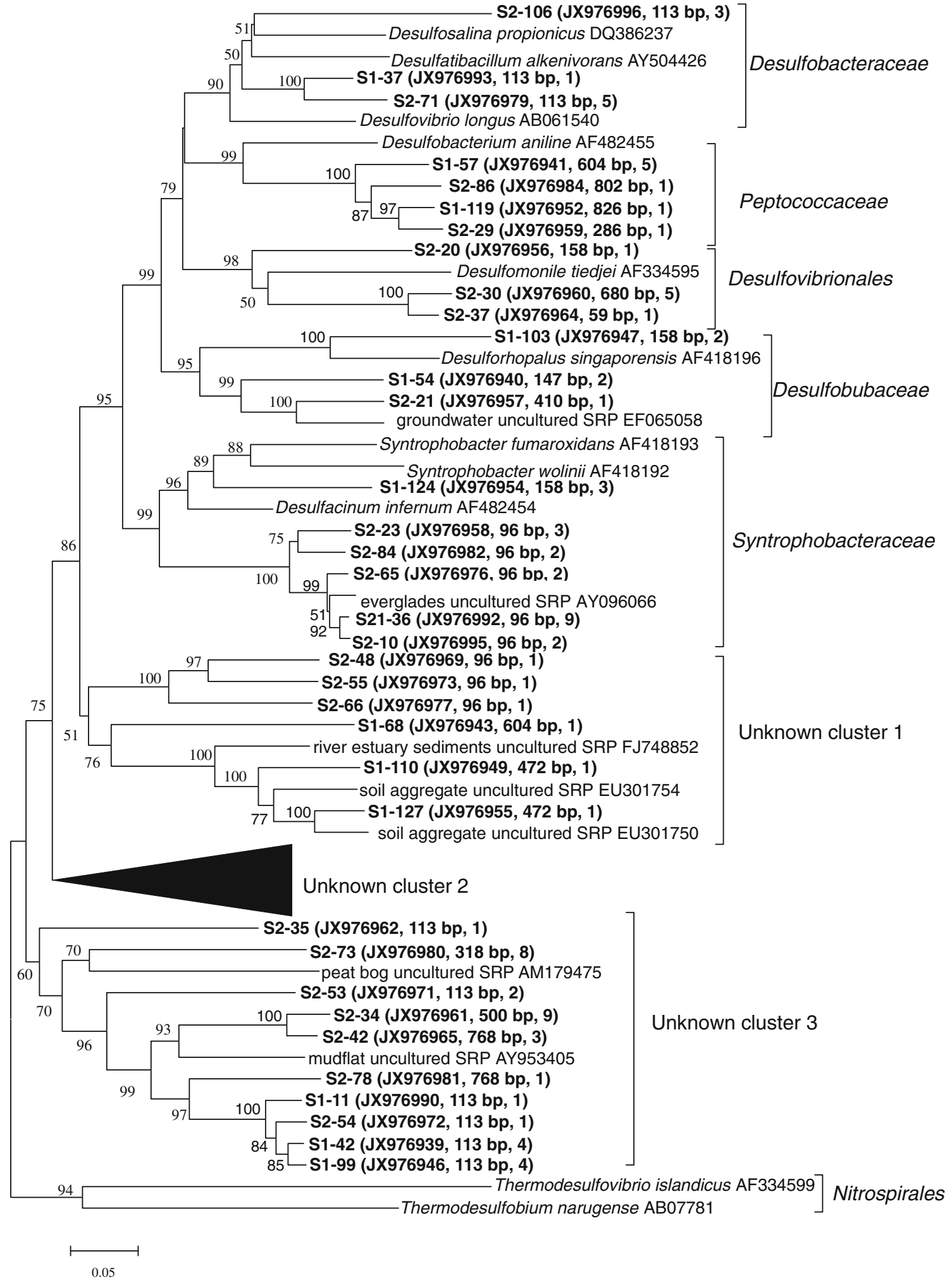

Fig. 5 Neighbour-joining tree of $d s r A B$ gene sequences retrieved from top soils in the Wanshan $\mathrm{Hg}$ mining area. Designation of the clones includes the following information: site ( $S 1, S 2, S 3$, and $S 4$ ), clone code, nucleotide sequence accession number in the GenBank, followed by the length of terminal restriction fragments and the number of clones with similarities above $97 \%$ to the listed sequence in the clone library in the parentheses. Clones in bold indicated the dominant T-RFs detected by T-RFLP analysis. Bootstrap values $(>50 \%)$ were indicated at branch points. The scale bar represented $5 \%$ estimated sequence divergence 


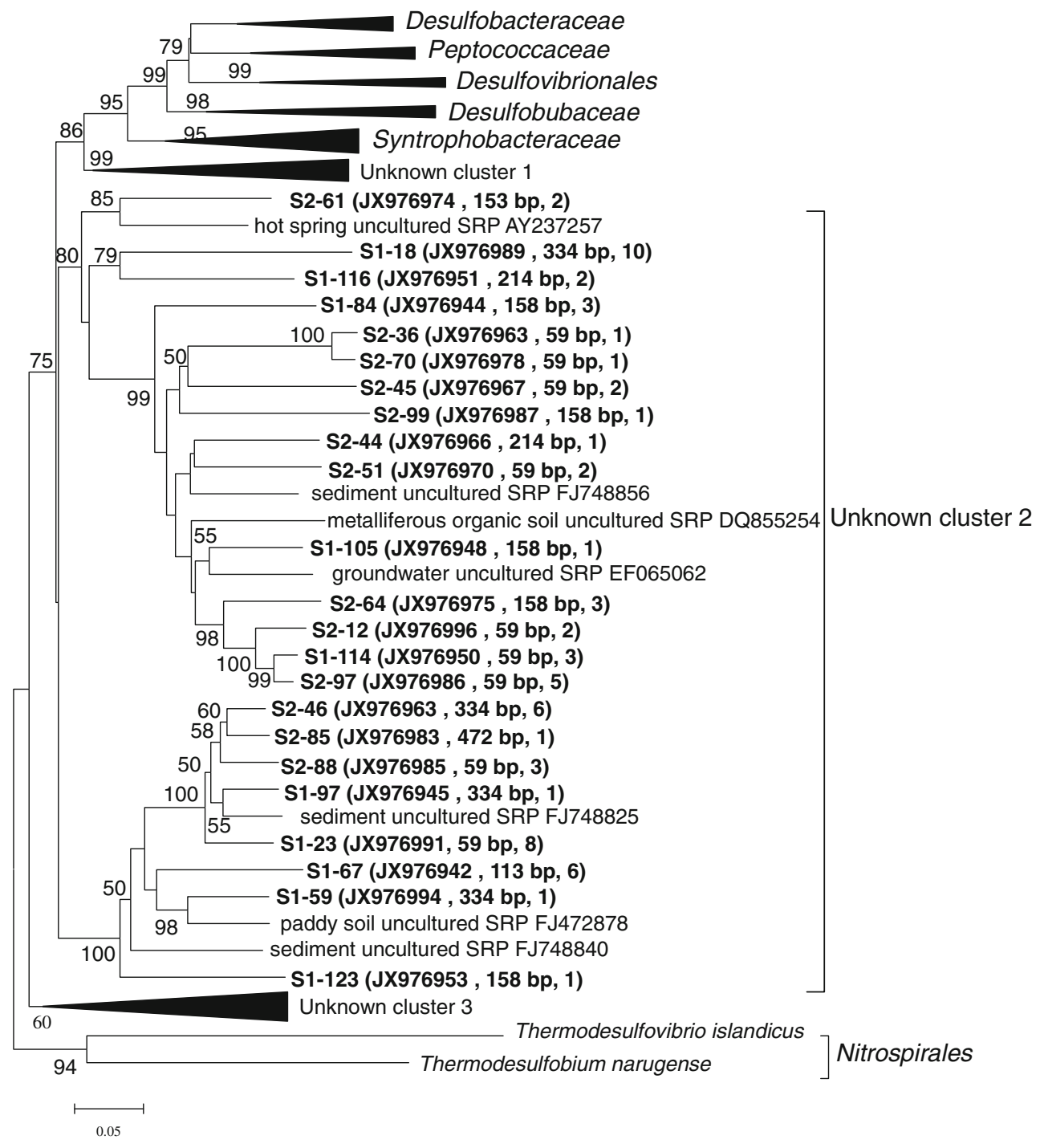

Fig. 5 (continued)

an adequate control site in the current study. Lower $(P<0.05)$ $\mathrm{Hg}$ contents in bottom soil $(60-80 \mathrm{~cm})$ of the four sites suggested this region originally probably had low natural $\mathrm{Hg}$ background. However, $\mathrm{Hg}$ content in top soil of S1 was approximately 20 times higher than mean $\mathrm{Hg}$ background levels. Since top soil is generally considered to be the arable layer, high $\mathrm{Hg}$ level in this layer poses a serious health risk to local rice safety due to its possible transformation and accumulation by rice roots.

Similarly, average $\mathrm{MeHg}$ contents in the soils decreased with geographical distance away from the historic $\mathrm{Hg}$ mine site. Higher $\mathrm{MeHg}$ concentrations of top soil over those of deep soil were found at $\mathrm{S} 1$ and $\mathrm{S} 2$, while no significant difference of them was observed in the S3 and S4. These could be explained partially by that the $\mathrm{MeHg}$ concentration in the soils was significantly correlated with $\mathrm{Hg}$ content (Table 2). Generally, the soil having higher $\mathrm{Hg}$ content would probably provide more bioavailable Hg. Therefore, total $\mathrm{Hg}$ content in soil could be one of important factors potentially influencing $\mathrm{MeHg}$ concentration. Besides, $\mathrm{MeHg}$ concentration in the soils was also covariated by several other environmental factors including the abundance of SRM and contents of $\mathrm{OM}, \mathrm{SO}^{2-}$, and $\mathrm{NH}_{4}{ }^{+}$. SRMs are considered as main producers of $\mathrm{MeHg}^{+}$in anaerobic environments (Compeau and Bartha 1985; Compeau et al. 1992), so the abundance of SRM can potentially impact the $\mathrm{MeHg}$ content in the paddy soils. The correlation here between $\mathrm{MeHg}$ content and SRM abundance might further supported this point. In addition, our results are in accordance with previous studies suggesting that $\mathrm{SO}_{4}{ }^{2-}$ concentration was also an important factor that governs $\mathrm{Hg}$ methylation capacity in the environment (Branfireun et al. 1999; Acha et al. 2005; Sitte et al. 2010). High $\mathrm{SO}_{4}{ }^{2-}$ content in the soils examined might be helpful to the prevalence of some SRM that produced $\mathrm{MeHg}$ (Han et al. 2010), and this could explain partially why the $\mathrm{SO}_{4}{ }^{2-}$ 
concentration are significantly correlated to the $\mathrm{MeHg}$ content. It was also suggested that $\mathrm{OM}$ can form strong complexes with $\mathrm{MeHg}^{+}$(Khwaja et al. 2010), which would be absorbed and fixed on soil. The correlation between the contents of $\mathrm{MeHg}$ and $\mathrm{OM}$ in the paddy soils might further support the previous observation. Therefore, avoidance of exogenous OM input into rice field during aerobic cultivation of rice plants could be an effective way to reduce the accumulation of $\mathrm{MeHg}$ in soil. Intriguingly, the content of $\mathrm{NH}_{4}^{+}$covariates on the $\mathrm{MeHg}$ concentration in the soils according to the Table 2, which could attribute to that the OM degradation in soils induced to the accumulation of $\mathrm{NH}_{4}^{+}$under anaerobic conditions.

\section{Abundance of SRM in soils}

The abundance of SRM in tested soil samples was positively correlated with the contents of $\mathrm{OM}, \mathrm{NH} 4+$ and $\mathrm{MeHg}$ (Table 2, Fig. 3). Average abundance of $d s r A B$ gene in these soils was $6.04 \times 108$, which was comparable to the previous studies based on the sites without $\mathrm{Hg}$ or other pollution (Scheid and Stubner 2001; Liu et al. 2009). These could indicate that the SRM abundance was not influenced by the level of pollution. No significant relationship was observed between the abundance of SRM and the Hg contents in the soils at the four sites, suggesting that long-term $\mathrm{Hg}$ contamination did not changed abundance of SRM in the present study. This result was different from the previous studies based on short-term incubation experiments showing a negative influence of $\mathrm{Hg}$ pollution on the abundance of microorganism (Liu et al. 2010; Zhou et al. 2012). These different effects could be attributed to their different polluted duration by $\mathrm{Hg}$, and some microbial groups in soil might exhibit some resistance or adaptation to long-term $\mathrm{Hg}$ stress (Barkay et al. 2003). For each site, total abundances of the $d s r A B$ gene in $0-40 \mathrm{~cm}$ soil were significantly higher than those in the 40 $80 \mathrm{~cm}$ soil $(P<0.05)$. Those could be partially explained by that $\mathrm{OM}$ contents in the layers were higher compared to those in 40-80 cm depth soils. Abundance of SRM was correlated significantly with OM contents based on results of the correlation analysis, suggesting that relatively high levels of OM may provide favorable conditions for SRM growth in the soils. Additionally, more OM content in soil might induce more ammonification resulting in accumulation of $\mathrm{NH}_{4}{ }^{+}$in anaerobic conditions, and this may be why $\mathrm{NH}_{4}{ }^{+}$ content was significantly correlated with SRM abundance.

Diversity of SRM and phylogenetic analysis

The present study used T-RFLP method to analysis the community structure of SRM in the paddy soils with different $\mathrm{Hg}$ contents. A total of 29 T-RFs were detected at the four soil sites where 59, 96, 113, and 158 bp T-RFs dominated ( $>50 \%)$ for SRM (Fig. 4). Phylogenetic analysis of $d s r A B$ gene revealed 9 distinct clusters, and their affiliations to distinct T-RFs are evident in Fig. 5. Less than $30 \%$ of sequences obtained were grouped into a known SRM cluster. The $113 \mathrm{bp}$ T-RF were mainly grouped into Desulfobacteraceae in the both of clone libraries, while most 96 bp T-RFs were affiliated with the Syntrophobacteraceae group. Overall, $40 \%$ of detected sequences was grouped into unknown cluster 2 , which mainly consisted of most 59 and 158 T-RFs.

No significant difference of diversity (Shannon index) was observed for among the soils from different sites or depths based on T-RFLP analysis of $d s r A B$ (data not shown). However the percentage of specific sequences in each soil at the four sites was different (Fig. 4), which could exert different functions of $\mathrm{Hg}$ methylation because of taxonomic diversity (Yu et al. 2010). High proportion of 214 T-RF was found in the soil of S1 where the MeHg contents were highest, while no or small level of the $214 \mathrm{~T}$-RF could be observed at the other sites. This might suggest that this uncultured group could have adapted and exhibited some resistance to the Hg stress. Intriguingly, the CK site (S4) had the lowest proportion of $96 \mathrm{bp}$ T-RF (dominated by Syntrophobacteraceae group) compared to that at the other higher MeHg content sites. However, it is difficult to clarify its associations with the $\mathrm{MeHg}$ contents in the soils examined according to this study, which need further evidence to confirm this point. In addition, relatively high abundance of 604 bpT-RF belonging to Peptococcaceae was found in $\mathrm{S} 4$, which seemed to be sensitive to $\mathrm{Hg}$ stress and just grow well in a low Hg environment.

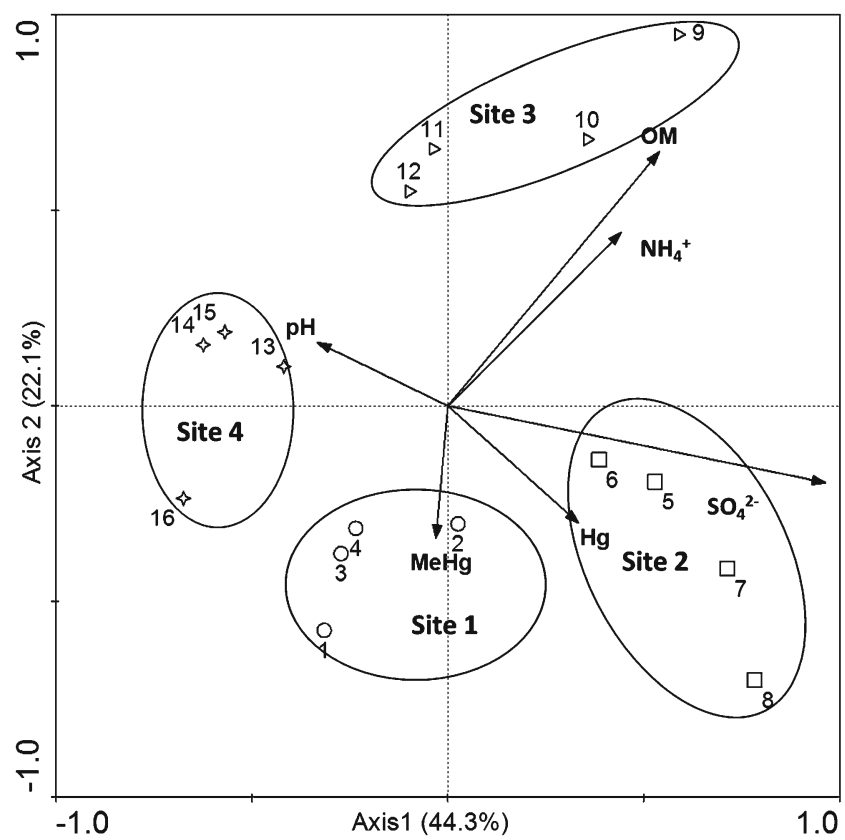

Fig. 6 Canonical correspondence analysis (CCA) between the SRM community and environmental variables of $\mathrm{pH}$ value, the contents of organic matter $(\mathrm{OM})$, total $\mathrm{Hg}$, methylmercury $(\mathrm{MeHg}), \mathrm{NH}_{4}{ }^{+}$, and $\mathrm{SO}_{4}{ }^{2-}$ in the soils. The meaning of symbols: circle represents $\mathrm{S} 1$, box represents $\mathrm{S} 2$, right triangle represents $\mathrm{S} 3$, and asterisk represents S4 
All of known SRM in the present study belonged to Deltaproteobacteria that had be suggested the only group can participate in Hg methylation (Ranchou-Peyruse et al. 2009). Some of unknown SRM could also play crucial role in $\mathrm{Hg}$ methylation, however up to date no evidence can prove it. Nearly half of the known $d s r A B$ sequences detected here belonged to the Syntrophobacteraceae. This may result from high sulfate concentrations in the soils since Syntrophobacteraceae have been suggested to be more common in presence of high sulfate content (Leloup et al. 2007). The majority of uncultured $d s r A B$ sequences detected here were related to environmental sequences retrieved from mudflat (Leloup et al. 2006), everglades (Castro et al. 2002), marine sediments (Jiang et al. 2009), hot springs (Fishbain et al. 2003), and paddy soil (He et al. 2010).

Relationship of SRM communities and soil environmental factors

Results of the CCA analysis based on the T-RFLP data suggested that SRM community structure in the soils studied was influenced or covariated substantially by soil environmental variables, and the effect of individual environmental factors was different in each of the four sites (Fig. 6). The four soil horizon samples taken at each site in general, clustered togeth$\mathrm{er}$ in the CCA profile, indicating that distance from the $\mathrm{Hg}$ mining site influenced SRM community distribution.

It appears that soil SRM community structure at S1 could be influenced by $\mathrm{MeHg}$ content according to the CCA profiles, which might be associated with the higher $\mathrm{MeHg}$ content posing a relatively higher toxicity to soil microorganisms. Soil OM and $\mathrm{NH}_{4}^{+}$contents appeared to have a strong effect on the SRM community diversity at S3. Previous studies have suggested that the OM levels play important role on influencing microbial communities (He et al. 2007; Leloup et al. 2009), and results of our study add partial support for this view. As a substrate for sulfate reduction in soils, sulfate concentration may also exert a crucial role in influencing SRM community composition according to the CCA analysis. To get a more comprehensive insight into the effects of environmental factors on the SRM community in paddy soils, further studies using samples from different soil types and at a larger spatial scale are therefore needed.

\section{Conclusions}

This study showed a linkage between the SRM diversity and $\mathrm{MeHg}$ levels, indicated by the analysis of correlation between the abundance of SRM and concentrations of $\mathrm{MeHg}$ in the soils. The association implied the importance of SRM for $\mathrm{MeHg}$ concentration in anaerobic rice fields. However, the content of $\mathrm{OM}, \mathrm{SO}_{4}{ }^{2-}, \mathrm{NH}_{4}{ }^{+}$, and $\mathrm{Hg}$ could also impact the $\mathrm{MeHg}$ concentration in paddy soil. Soil SRM community composition varied among the different sites, which could be determined by several environmental variables, such as OM content. Some new unknown SRM groups were reported in this study, which is of importance to recognize the relationship between SRM diversity and $\mathrm{Hg}$ methylation in paddy soil.

Acknowledgments This work was supported by the National Natural Science Foundation of China (41201523, 41090281). We would like to thank Professor Peter Mather for improving English and Mr. Shi Xingwang for assistance in soil sampling.

\section{References}

Acha D, Iniguez V, Roulet M, Guimaraes JR, Luna R, Alanoca L, Sanchez S (2005) Sulfate-reducing bacteria in floating macrophyte rhizospheres from an Amazonian floodplain lake in Bolivia and their association with $\mathrm{Hg}$ methylation. Appl Environ Microbiol 71:7531-7535

Barkay T, Miller SM, Summers AO (2003) Bacteria mercury resistance from atoms to ecosystems. FEMS Microbiol Rev 27:355-384

Benoit JM, Gilmour CC, Mason RP (2001) Aspects of bioavailability of mercury for methylation in pure cultures of Desulfobulbus propionicus (1pr3). Appl Environ Microbiol 67:51-58

Branfireun BA, Roulet NT, Kelly CA, Rudd JWM (1999) In situ sulphate stimulation of mercury methylation in a boreal peatland: Toward a link between acid rain and methylmercury contamination in remote environments. Glob Biogeochem Cycles 13:743-750

Cao P, Zhang LM, Shen JP, Zheng YM, Di HJ, He JZ (2012) Distribution and diversity of archaeal communities in selected Chinese soils. FEMS Microbiol Ecol 80:146-158

Castro H, Reddy KR, Ogram A (2002) Composition and function of sulfate-reducing prokaryotes in eutrophic and pristine areas of the Florida Everglades. Appl Environ Microbiol 68:6129-6137

China National Environmental Monitoring Station (CNEMS) (1990) Background elemental concentrations of Chinese soils. Environmental Science Press, Beijing, China (in Chinese)

Choi SC, Chase T, Bartha R (1994) Metabolic pathways leading to mercuty in Desulfovibrio-desulfuricans LS. Appl Environ Microbiol 60:4072-4077

Coates JD, Anderson RT, Lovley DR (1996) Oxidation of polycyclic aromatic hydrocarbons under sulfate-reducing conditions. Appl Environ Microbiol 62:1099-1101

Compeau GC, Bartha R (1985) Sulfate-reducing bacteria: principal methylators of mercury in anoxic estuarine sediment. Appl Environ Microbiol 50:498-502

Dhillon A, Teske A, Dillon J, Stahl DA, Sogin ML (2003) Molecular characterization of sulfate-reducing bacteria in the Guaymas Basin. Appl Environ Microbiol 69:2765-2772

Duran R, Ranchou-Peyruse M, Menuet V, Monperrus M, Bareille G, Goni MS, Salvado JC, Amouroux D, Guyoneaud R, Donard OFX, Caumette P (2008) Mercury methylation by a microbial community from sediments of the Adour Estuary (Bay of Biscay, France). Environ Pollut 156:951-958

Ekstrom EB, Morel FMM, Benoit JM (2003) Mercury methylation independent of the acetyl-coenzyme a pathway in sulfatereducing bacteria. Appl Environ Microbiol 69:5414-5422

Feng X, Li P, Qiu G, Wang S, Li G, Shang L, Meng B, Jiang H, Bai W, Li Z, Fu X (2008) Human exposure to methylmercury through rice intake in mercury mining areas, guizhou province, China. Environ Sci Technol 42:326-332

Fishbain S, Dillon JG, Gough HL, Stahl DA (2003) Linkage of high rates of sulfate reduction in Yellowstone hot springs to unique 
sequence types in the dissimilatory sulfate respiration pathway. Appl Environ Microbiol 69:3663-3667

Fitzgerald WF, Lamborg CH, Hammerschmidt CR (2007) Marine biogeochemical cycling of mercury. Chem Rev 107:641-662

Geets J, Borremans B, Diels L, Springael D, Vangronsveld J, Lelie DVD, Vanbroekhoven K (2006) DsrB gene-based DGGE for community and diversity surveys of sulfate-reducing bacteria. J Microbiol Methods 66:194-205

Gilmour CC, Henry EA, Mitchell R (1992) Sulfate stimulation of mercury methylation fresh-water sediments. Environ Sci Technol 26:2281-2287

Han S, Narasingarao P, Obraztsova A, Gieskes J, Hartmann AC, Tebo BM, Allen EE, Deheyn DD (2010) Mercury speciation in marine sediments under sulfate-limited conditions. Environ Sci Technol 44:3752-3757

He JZ, Liu XZ, Zheng Y, Shen JP, Zhang LM (2010) Dynamics of sulfate reduction and sulfate-reducing prokaryotes in anaerobic paddy soil amended with rice straw. Biol Fertil Soils 46:283-291

He JZ, Shen JP, Zhang LM, Zhu YG, Zheng YM, Xu MG, Di HJ (2007) Quantitative analyses of the abundance and composition of ammonia-oxidizing bacteria and ammonia-oxidizing archaea of a Chinese upland red soil under long-term fertilization practices. Environ Microbiol 9:3152-3152

Hsu-Kim H, Kucharzyk KH, Zhang T, Deshusses MA (2013) Mechanisms Regulating Mercury bioavailability for methylating microorganisms in the aquatic environment: a critical review. Environ Sci Technol 47:2441-2456

Heyes A, Mason RP, Kim EH, Sunderland E (2006) Mercury methylation in estuaries: Insights from using measuring rates using stable mercury isotopes. Mar Chem 102:134-147

Jiang L, Zheng Y, Peng X, Zhou H, Zhang C, Xiao X, Wang F (2009) Vertical distribution and diversity of sulfate-reducing prokaryotes in the Pearl River estuarine sediments, Southern China. FEMS Microbiol Ecol 70:249-262

Khwaja AR, Bloom PR, Brezonik PL (2010) Binding Strength of Methylmercury to Aquatic NOM. Environ Sci Technol 44:6151-6156

King JK, Kostka JE, Frischer ME, Saunders FM (2000) Sulfate-reducing bacteria methylate mercury at variable rates in pure culture and in marine sediments. Appl Environ Microbiol 66:2430-2437

Leloup J, Quillet L, Berthe T, Petit F (2006) Diversity of the dsrAB (dissimilatory sulfite reductase) gene sequences retrieved from two contrasting mudflats of the Seine estuary, France. FEMS Microbiol Ecol 55:230-238

Leloup J, Loy A, Knab NJ, Borowski C, Wagner M, Jorgensen BB (2007) Diversity and abundance of sulfate-reducing microorganisms in the sulfate and methane zones of a marine sediment, Black Sea. Environ Microbiol 9:131-142

Leloup J, Fossing H, Kohls K, Holmkvist L, Borowski C, Jorgensen BB (2009) Sulfate-reducing bacteria in marine sediment (Aarhus Bay, Denmark): abundance and diversity related to geochemical zonation. Environ Microbiol 11:1278-1291

Li JJ, Zheng YM, Yan JX, Li HJ, He JZ (2013) Succession of plant and soil microbial communities with restoration of abandoned land in the Loess Plateau, China. J Soils Sediments 13:760-769

Liang L, Horvat M, Feng XB, Shang LH, Li H, Pang P (2004) Reevaluation of distillation and comparison with $\mathrm{HNO}_{3}$ leaching/ solvent extraction for isolation of methylmercury compounds from sediment/soil samples. Appl Organomet Chem 18:264-270

Lin H, Shi J, Chen X, Yang J, Chen Y, Zhao Y, Hu T (2010) Effects of lead upon the actions of sulfate-reducing bacteria in the rice rhizosphere. Soil Biol Biochem 42:1038-1044

Liu XZ, Zhang LM, Prosser JI, He JZ (2009) Abundance and community structure of sulfate reducing prokaryotes in a paddy soil of southern China under different fertilization regimes. Soil Biol Biochem 41:687-694
Liu YR, Zheng YM, Shen JP, Zhang LM, He JZ (2010) Effects of mercury on the activity and community composition of soil ammonia oxidizers. Environ Sci Pollut Res 17:1237-1244

Liu YR, He JZ, Zhang LM, Zheng YM (2012) Effects of long-term fertilization on the diversity of bacterial mercuric reductase gene in a Chinese upland soil. J Basic Microbiol 52:35-42

Meng B, Feng XB, Qiu GL, Cai Y, Wang DY, Li P, Shang LH, Sommar J (2010) Distribution patterns of inorganic mercury and methylmercury in tissues of rice (Oryza sativa L.) plants and possible bioaccumulation pathways. J Agric Food Chem 58:4951-4958

Pak KR, Bartha R (1998) Mercury methylation by interspecies hydrogen and acetate transfer between sulfidogens and methanogens. Nucleic Acids Res 64:1987-1990

Parks JM, Johs A, Podar M, Bridou R, Hurt RA Jr, Smith SD, Tomanicek SJ, Qian Y, Brown SD, Brandt CC, Palumbo AV, Smith JC, Wall JD, Elias DA, Liang L (2013) The Genetic Basis for Bacterial Mercury Methylation. Science 339:1332-1335

Ranchou-Peyruse M, Monperrus M, Bridou R, Duran R, Amouroux D, Salvado JC, Guyoneaud R (2009) Overview of mercury methylation capacities among anaerobic bacteria including representatives of the sulphate-reducers: implications for environmental studies. Geomicrobiol J 26:1-8

Schaefer JK, Rocks SS, Zheng W, Liang L, Gu B, Morel FMM (2011) Active transport, substrate specificity, and methylation of $\mathrm{Hg}(\mathrm{II})$ in anaerobic bacteria. Proc Natl Acad Sci USA 108:8714-8719

Scheid D, Stubner S (2001) Structure and diversity of Gramnegative sulfate-reducing bacteria on rice roots. FEMS Microbiol Ecol 36:175-183

Schmalenberger A, Drake HL, Kusel K (2007) High unique diversity of sulfate-reducing prokaryotes characterized in a depth gradient in an acidic fen. Environ Microbiol 9:1317-1328

Sitte J, Akob DM, Kaufmann C, Finster K, BanerjeeD BEM, Kostka JE, Scheinost AC, Buechel G, Kuesel K (2010) Microbial Links between sulfate reduction and metal retention in uranium- and heavy metal-contaminated soil. Appl Environ Microbiol 76:3143-3152

Smith CJ, Nedwell DB, Dong LF, Osborn AM (2006) Evaluation of quantitative polymerase chain reaction based approaches for determining gene copy and gene transcript numbers in environmental samples. Environ Microbiol 8:804-815

Thompson JD, Higgins DG, Gibson TJ (1994) CLUSTAL W: improving the sensitivity of progressive multiple sequence alignment through sequence weighting, position-specific gap penalties and weight matrix choice. Nucleic Acids Res 22:4673-4680

Todorova SG, Driscoll CT Jr, Matthews DA, Effler SW, Hines ME, Henry EA (2009) Evidence for Regulation of Monomethyl Mercury by Nitrate in a Seasonally Stratified, Eutrophic Lake. Environ Sci Technol 43:6572-6578

Walkley A, Black IA (1934) An examination of the Degtjareff method for determining soil organic matter, and a proposed modification of the chromic acid titration method. Soil Sci 37:29-38

Yu RQ, Adatto I, Montesdeoca MR, Driscoll CT, Hines ME, Barkay T (2010) Mercury methylation in Sphagnum moss mats and its association with sulfate-reducing bacteria in an acidic Adirondack forest lake wetland. FEMS Microbiol Ecol 74:655-668

Yu RQ, Flanders JR, Mack EE, Turner R, Mirza MB, Barkay T (2012) Contribution of coexisting sulfate and iron reducing bacteria to methylmercury production in freshwater river sediments. Environ Sci Technol 46:2684-2691

Zhang H, Feng XB, Larssen T, Shang L, Li P (2010) Bioaccumulation of methylmercury versus inorganic mercury in rice (Oryza sativa L.) grain. Environ Sci Technol 44:4499-450

Zhou ZF, Zheng YM, Shen JP, Zhang LM, Liu YR, He JZ (2012) Responses of activities, abundances and community structures of soil denitrifiers to short-term mercury stress. J Environ Sci 24:369-375 